\title{
DEMOCRACY AND DEVELOPMENT: THE NIGERIAN EXPERIENCE
}

\section{S. I. EBOHON AND C. O. EMUEDO}

(Received 10, June 2009; Revision Accepted 10, August 2009)

\begin{abstract}
The conventional notions on the relationship between democracy and development are that democracy accelerates development. Based on the Nigeria experience, this paper argues that both democracy and authoritarianism are social system based political ideologies that derives their character from the wider society, which is conservative. Thus, issues that characterised military autocracy; denial of human rights, corruption, mismanagement and poverty have continued to replicate in the nascent democracy from 1999 to date. It therefore postulates that the permeability of democratic-authoritarian boundaries makes for virus replication across regime typologies in an open political system.
\end{abstract}

\section{INTRODUCTION}

There is a general assumption that richer countries are generally democratic (Persson and Tabellin, 2006). This popular opinion holds that democratic capitalism, anchored on free enterprise system, unleashes the latent potentials of citizens for national economic and technological growth. This kind of generalisation, popularised by liberal western scholars as well as their intellectual prodigies in Asia and Africa, may have influenced the reinvention of Marxism-Leninism in Soviet Union and Eastern Europe; giving rise to the construction of democratic partocracy (Single party democracy). The exploded data during the last two decades, suggest that this generalisation suffers from the fallacy of reverse causation or omitted variables. Therefore, the scientific credential of this hypothesis is suspect.

The authoritative body of empirical data available remain divided on the nature of the relationship between democracy and development. The study by Sirowy and Inkeles (1991) is supportive of negative relationship between democracy and development; one by Compos (1994) is of generally positive relationship; the one by Prezeworski and Limongi (1993) is agnostic ("we do not know whether democracy fosters or hinders economic growth").
The dominant trend of thinking in Nigeria, like elsewhere in Africa, is the single-minded focus on regular conduct of election that offered citizens a choice between alternative set of rulers; military and civilians with no attention given to relationship between citizens and rulers leading up to the holding of such presumably "free and fair" election or to those prevailing after such episodic events (Philippe Schmitter, 2003:1). Such citizen rulerrelations as defined by citizen equality or access to resources or benefits, access to opportunities for upward social mobility, freedom of speech, universal suffrage, constituting the bill of democratic particulars; are generally viewed as normative ideal-type construct. The mass failure of multi-party democracy in Nigeria like elsewhere in Africa triggered military provenance in politics. In the context of new African states, democracy is simply politically contrived or foisted in the peoples' psyche to mean transition from military command system to civil democratic rule with no attention to the crucial phenomenon of transition within transition. Thus, emphasis is on the urgent need to end military rule, to drive military junta out of public space, to disengage the military, to institute a political system based on universal adult suffrage. Democracy has thus, become a political necessity and a fashion. Yet, effort in this direction since 1960 has not proved very fruitful.

S. I. Ebohon, Department of Political Science and Public Administration, University of Benin, Benin city C.O. Emuedo, Department of Political Science and Public Administration, University of Benin, Benin city 
Democracy as a set of modern political values must capture certain aggregate conditions that drive the political, social, cultural and economic conditions of a nation. In order words, certain legal and institutional prerequisites must be in place to set the context for a new value system. The repeat performance of the poverty of Nigerian politics derives not so much from the military's obsession with power as with the logic and conception of the Nigerian state, politics and system of power.

This paper is presented around five themes. Section I introduces the controversy while section II clarifies the concepts democracy and authoritarianism. In section III development is recaptured, while, section IV presents the framework of the discussion. Sections $V$ and VI discuss the Nigerian experience and concluding observations respectively.

\section{Democracy and Authoritarianism}

As our point of departure, we ask the question: what is democracy? Democracy has been eulogised in the western literature of development that the neo-imperial states hold it as the key to liberation from repressive state and the crisis of underdevelopment engendered by the military's assault on post-colonial democracies in Africa. Within the context of the ongoing epistemological controversy over the relationship between democracy and authoritarianism as activators or suppressors of development, this paper seeks empirical evidence from Nigeria.

The search for a generic definition of democracy is fraught with intense conceptual and epistemological confusion. The most popular roadside conception of democracy is government by the people for the people. A leading political scientist defined democracy as "a form of government in which the rulers are fully responsible to the ruled in order to realise self respect for every body" (Riker, 1965:31).

Schmitter (2003) however, opines that Riker's definition fails to capture the generic quality of democracy and says instead that democracy is a "regime or system of government in which rulers are held accountable for their action in the public domain by citizens acting indirectly through the competition and co-operation of their representatives".

Such a generic definition does not capture the gamut of democratic credentials articulated by earlier proponents. A more embracing articulation puts it this way; democracy as conventionally conceived - defined by regular elections with comprehensive suffrage and responsiveness of the state, to the elected representatives and underpinned by freedom of speech and association is only possible if political decisions are to some extent separated from the system of class and status and power (Rueshchemeuer, 2001:24). Riker's definition is only concerned with political representation to the neglect of the rising profile of corporate governance in decision making process of contemporary post developed societies. Given the failure of the exploded literature on democracy to capture a generally acceptable definition of democracy, we shall simply resort to the democratic bill of particulars that are generally adopted as the central indices in democratic audit; guarantee of freedom speech, respect for human rights and equality before the law.

Authoritarianism on the other hand, is a political system in which the government tolerates little or no opposition to its rule but may allow nongovernmental centres and functionaries to influence and debate certain government policies (Hughes, Kroehler et al, 2002:286). A large number of African and Latin American countries ruled by military regimes are authoritarian. In the same vein, since the death of Stalin in 1953 and Mao in 1976, Soviet Union until 1991 and China up to the present progressively took on the properties of authoritarian states respectively, through a policy of selective repression and the widening of the range of permissible discussion and debate. The emergent patterns in these states marked the end of totalitarianism.

\section{The Concept of Development}

Whenever the concept of development and democracy appear together in political discourse, the need to give sufficient time and space to a clarification of the concept of development is often omitted. Three explanations for the neglect of the concept of development are germane. The first is that the concept of development is assumed clarified in every day discourse. The second explanation is that any marriage of the two concepts relegates development concepts to the background as the main issue is politics and political office holding. The third explanation is that the two concepts mean almost the same thing in two adjacent disciplines of economics and political science.

Development literally refers to movement from one stage of economic being to another in strictly economistic sense. It refers to such economic indicators as increase in national income, gross domestic product, national per capital income, the growth in the number of industries, changing tastes 
and new economic habits. Such rising economic profile may not necessarily translate to development in strictly economic sense as they only point to growth in these indicators.

Modern economists have come to question the usefulness of these indicators as measures of development, because they tell us very little about the spread effect of these indicators. Can the growth translate to new jobs, can industrial and inter-sectoral linkages be enhanced, can ruralurban disarticulation be impacted on? Thus, a new body of economic literature have emerged to question a pattern of development that cannot unleash the latent potentials of the national economy in such a way as to enhance aggregate efficiency in resource deployment and utilisation to reduce production cost, reduce prices and reduce poverty and improve the lots of the masses and the middle class.

While the economists use these indicators for development, the sociologists look at the prospect for the emergence of alternative social structure where inter-generational and intra-generational upward mobility are guaranteed. The political scientists are concerned with the power gain associated with the economic indicators and thus, the extent to which the hitherto poor become politically relevant and acquire the necessary resources needed to participate in decision-making on issues affecting their lives.

A new school of thought (the developmentalist adopting the methodology of multidisciplinary synthetic trajectory) has emerged to question these currents of thought and is making a case for sustainable human development as a strategy that puts the power to create wealth and good life in the hands of the people themselves. This is deemed the best guarantee against extraversion in favour of auto-centric development that can generate the logic of internally driven national economy.

Interface Political Virus: The Iron Law of negative Entropy in an Open Political System.

The state in the classical western discourse and political practice is an impartial arbiter in the struggle between contending social classes in western societies, (Appadorai 2003:41) because it enjoys relative autonomy. The notion of distinct relative autonomy of the state in Pakistan and Bangladesh broached by Hamza Alavi points to the uniqueness of the post-colonial state as distinct from its western intellectual and moral rationalisation (Alavi, 1972:59-80). The salience of the state in this discourse, derives from its objective moral and constitutional reality as the context of social and political action in society.

The state in Africa has been variously described "over developed" (Leys, 1976; Swollen Swaison, 1977) as the instrument of the ruling class (Ake, 1978, 1981) and prebendal (Joseph, 1991). As others point to the phenomenon of estranged society or state society disjuncture, Claphan, (1993) developed the notion of the crisis of African statehood engendered by the politics of de-stated societies. Similarly, on the basis of contemporary empirical evidence from Nigeria Ebohon, (2008) made a case for privatisation and personalisation of the state in a praetorian democracy in Nigeria.

In the context of incipient and distorted states, what has been the distinctive character of democracy? What has been the distinctive character of autocracy? What has been happening to the state? What has been the distinctive regimes' character of development? Evidence of inter-regime performance profile suggests unity and convergence. To capture and explain the unity and convergence of democracy and autocracy as explanatory variables for the crisis of the Nigerian political project, we here postulate; there is interfacing of political virus across regime boundaries.

Our iron law of negative entropy ${ }^{1}$ in the Nigerian political system makes the following propositions;

1. there is virus inter-facing between regime types;

2. the amount of virus that disappears from a fallen regime, tends to appear in the alternative regime;

3. regime boundaries tend to be open and therefore permeable;

4. the elements of the virus are corruption, privatisation of the state realm and absence of accountability in administration; and

5 therefore, authoritarianism and democracy tend to play out similar historical conjuncture in the Nigerian project.

The phenomenon conduces regime identity across board. Such virus inter-facing enhances regime capacity to survive the natural entropic process of disorganisation and death by building the negative entropy for system survival in a manner typical of negative entropy in physical systems. The law of entropy states that complex physical systems move towards simple random distribution of their elements when subjected to heat in order to maintain equilibrium. As is well documented, in the 
long run, all open systems are subject to the law of entropy; they lose input or the ability to transform them and die. While, they live however, the entropic process is arrested or reversed. The cycle of input transformation and output is essential to the system life and it is the cycle of negative entropy (Kahn, 1978:25). This law of physical science is replicable in the Nigerian political system.

The basic assumptions of our iron law of negative entropy are;

1. the Nigerian political sub-system is not just a part of the holistic process of state but more importantly, a central and dominant driver of the state system and process;

2. the system operators have similar background characteristics; but share different personal interest that threaten the state;

3 incipient statehood limits the capacity of the state to subordinate personal interest to the wider imperative of state survival and state integrity;

4. the Nigerian state like elsewhere in Africa is a mere pawn in the hands of the political classes yanked about for personal dreams of corporate and class interests; and

5 authoritarian or democratic developmentalism are methods of change that change little in Nigerian politics.

To restate our theses the systemic virus that conduce autocracy and democracy to personal projects produce alternative governments along old systemic identity and performance character; with different credentials. It runs further, neither autocracy nor democracy has fought corruption and executed the national project that inform their emergence. The provenance of the political army, with its avowed mission of fighting corrupt politicians has been betrayed by the brazen corruption that marked the entire regimes of the political armies. Similarly, Balewa democracy 1960-1966, the Shagari project 19791983 and the Obasanjo democratic restoration project were at best rogue aristocracies with veneer of democratic developmentalism.

\section{Democracy and Authoritarianism: Comparative Assessment}

Before we attempt to empirically substantiate the thesis broached in our framework, a brief observation is necessary. The popularity of democracy (to the average Nigerian) derives more from its political market place presentation than Nigeria's earlier experience with its practice. Nigeria's quest for democracy during colonial rule was based on its moral idealisation by the west during the peak of the Cold War. If any thing, this over romanticised view of democracy was betrayed by the crisis and corruption that undermined the first republic; an experience Nigerians continue to dread. At the end of the Cold War, certain negative disqualifiers were fashioned to dress the emerging democracies; façade, semi, impartial, incomplete, illiberal, sham "defective" low intensity pseudophoney "delegative" etc. The new dress code was designed to show that the new democracies were not classical democracies of the western world. However, we are not here concerned with democratic quality in relative sense but with a comparative assessment of military/democratic nexus within the Nigerian state context. We shall therefore, capture the performance of the military and the politicians and put the two regime types in developmental matrix to underscore the thrust of this paper.

\section{Politics of Human Rights}

The politics of human rights violation dates back to 1962 (first republic) when barely two years after independence, the Balewa administration declared a state of emergency under which opposition leader; Chief Obafemi Awolowo and his lieutenants were tried for treason and jailed. Similarly, the full character of the political army was unleashed in 1967 when Gowon in a pre-emptive attempt to nip in the bud the possible outbreak of hostilities and eventual secession, promulgated the Decree 24, which vested the military with arbitrary powers over the Nigerian state. Subsequent military juntas from Buhari to Abacha retained this decree with minor amendments; leading to waste of many lives under Abacha (Akhaine, 2006:21).

Although human rights violation was not a prominent feature of military authoritarianism until the Babangida coup employed the concept as his justification for the Buhari ouster in August 1985, contemporary history has credited his junta with the activation of human rights violation virus inherent in authoritarianism. While the protesters against the regime's unpopular SAP programmes were arrested and detained under several prisons across the country, it is his "permanent transition" that we must situate the contradictions that stood at the base of the regime's ascendancy and the junta's assault on the political freedom of 
Nigerians. Dare aptly captured the character of his project;

"As General Ibrahim Babangida's
transition programme (1985-1993)
launched from
one duplicitous interpolation to another
and as each minor advance was lavishly
celebrated as a stroke of genius only to
be annulled by double summersault, his
intellectual court jesters were always at
hand with an explanation. The entire
scheme they said, discontinuity after
discontinuity was a carefully-programmed
learning process with an inbuilt self-
correcting mechanism".

The hidden agenda of this regime of endless permanent transition project was soon betrayed by Babangida's annulment of June 12, 1993 presidential election (won by Chief M.K.O. Abiola) adjudged the freest in Nigeria's political history. The constituted Interim National Government alternative was soon overthrown after 82 days to pave way for Nigeria's most draconian military authoritarian adventurer, General Sanni Abacha, who blinded by unscrupulous and overlapping ambition sought life presidency of the Nigerian State. However, though his dream failed following his mysterious death, he wasted lives of opposition leaders, gagged the press and earned for Nigeria, international sanctions and pariah status.

The euphoria that greeted the end of command state military authoritarianism on May 29, 1999 was soon to bubble and burst into the thin air. Thus, the revolution of rising expectation was displaced by the revolution of rising frustration as the new Obasanjo democracy was soon to leapfrog into another Super-Story of human rights violations. It is however, worthy of note that democracy under Obasanjo widened the political space for opposition. The number of registered political parties increased from 3 in 1999 to 50 in 2007. Similarly, the media industry blossomed; there were over 60 newspapers and magazines, 40 television stations and about 50 radio houses by 2005 . This performance is un-precedented in Nigeria's political history. While this gesture sounds democratic, it was designed as a mere veneer of democracy; (he refused to sign the Freedom of Information Bill passed by the National Assembly for over 2 years before vacating office). Thus, multi-partism in Nigeria simply engendered single party dominance and temptations as proliferation of parties undermine the prospect for the emergence of organised viable, self-sustaining and credible opposition through the fission of organisational and financial resources.

Driven by contradictory policies of irrational mutation the Obasanjo democracy denied opposition parties of legitimate funding. Opposition parties were equally denied police permit to organise rallies. At another level of the convoluted contradictions, some rallies were broken by the police and security agencies in defiance of existing police permit. In one such instance, a PDP decampee, former LSE political science Reader and former Senate President Dr. Chuba Okadigbo was fumigated out of life during a rally ... like an ordinary mosquito, with tear gas. Civil society organisations and labour movements, were similarly denied police permit to organise rallies.

As if the discredited and rigged elections of 1999 was not enough, the brazen deployment of the armed forces in support of the PDP during the second term bid in 2003 marked the elimination of a number of opposition leaders and PDP decampees as well as those whose loyalty the Obasanjo administration was not sure of. In a manner typical of acclamatory style democratic electioneering, Obasnajo as the leader of the PDP and head of the Nigerian state turned the party into a personal estate for punishing those who opposed his controversial third term bid. As the conscience of the PDP he exercised the right to throw out successful candidates at the primaries against the wish of the electorate at state, local and national levels. This action did not only violate political freedom but actually denied prospective gubernatorial and presidential candidates of their fundamental human rights ${ }^{2}$. It is important to note that the judiciary was not only undermined but also ignored in the selection as the process was deemed a family affair, with Obasanjo deciding who became governor in the states controlled by the PDP.

\section{The Economics of Authoritarian and} Democratic Developmentalism

The Nigerian State - from Balewa through Obasanjo democracy has been characterised as rent-seeking, dictatorial and anti-development (Akhaine, 2006). Thus, the state remains peripheral, dependent and extraverted. Its law of motion is governed by the logic of external accumulation rather than internal accumulation. In this circumstance and context, local value added is undermined by neo-imperial interest, while underdevelopment is constantly reproduced to 
sustain its dependent position in the new international division of labour. This location tells the story of perpetual culture of poverty, ruralurban dislocation and incoherence, tangential relations with the supposed metropolitan patrons as well as the attendant low capital formation, high infant mortality rate, high death rate, low per capital income and sub-human living conditions of the people since independence.

According to Festus lyayi, a World Heath Organisation Report on health situation in various countries of the world placed Nigeria 187 out of 191 countries that were surveyed in 2000. Similarly, the Human Development Report 2005 ranks Nigeria 158 out of 177 countries in the world covered in the evaluation. Ghana was ranked 138 while South Africa was ranked 120 on the HDI. For the 2000-2005 period, life expectancy at birth was estimated at 43.3 years for Nigeria compared to 56 for Ghana and 49 for South Africa. However, by 1998 during the days of the political army, life expectancy at birth was 51 years. Between 1998 and 2005 , every Nigerian born in that period had an average of 8 years removed from his life. In 2003 , infant mortality rate was estimated at 98 per 1000 live births for Nigeria. In Ghana and South Africa, the comparative figures were 59 and 53 respectively. Under 5 mortality rate per 1000 live births stood at 265 in Nigeria compared to 186 in Ghana in 2003. For the 2000-2005 periods, the probability at birth of surviving to age 55 for females in Ghana (52.9\%) was almost twice that of Nigeria (32\%) (lyayi, 2006).

Similarly, using an income level of N658.00 per month (\$8.20) to indicate the poverty line and N320.00 (\$4.00) to indicate extreme poverty; data from World Bank, Nigeria Office of Statistics (FOS) and UNDP, show that in 1980, the poverty level was $27.2 \%$ or 17.7 millions out of the estimated Nigerian population of 65 million (lyayi, 2006:2). By 1996, the level of poverty more than doubled to $65.6 \%$ or 67.1 million out of estimated population of 102.3 million people. The 1998 poverty figure stood at $70.2 \%$ or about 71 million people out of an estimated 105 million people. While the figure for the period 2000-2003 remained at $70.2 \%$ of the population, 87.5 million people lived below the poverty line of $\$ 1.00$ a day. During the same period $90.8 \%$ of the population or 112.7 million people lived on less than \$2 a day. By 2003 estimate, Nigeria ranked as the country with $3^{\text {rd }}$ largest population of poor people in the world. Current data for 2008 keeps Nigeria at the same level. Similarly, about $64 \%$ of the population of Nigeria was in control of less than $10 \%$ of national wealth while $20 \%$ controlled over $46 \%$ of the nation's wealth in 2000 (lbid).

The potent question to ask is this, how do we explain the velocity of decay and halt the journey towards Banana Island. IMF officials have been worried by a path of development, which earned Nigeria $\$ 350$ billion between 1965 and 2001 with nothing to show for it in terms of sound and efficient social infrastructure and well being of the people (Chizea and lyare 2006:90). The Economic and Financial Crimes Commission (EFCC) has equally submitted that past Nigerian rulers stole and misused $£ 220$ billion in the last four decades (Ibid:91). This figure equals all western aids to Africa in four decades. According to the Telegraph of London, "The looting of Africa's most populous country amounted to a sum equivalent to 300 years of British aid to the continent" (Telegraph of London, 2003:1-2).

A study of capital flight and Macroeconomic Growth in four African countries, Nigeria, Cote D' Ivoire, Morocco and Ghana by the debt Management Office revealed that Nigerians lost \$42 billion between 1971 and 2001. During Obasanjo's first outing as head of state, 19761979 , Nigeria lost $\$ 926$ million to capital flight. Buhari regime, 1984 to August 1985 lost \$1.978 billion while the Babangida era 1985 to 1993 recorded \$2.287 billion. However, Obasanjo's second outing as a democrat lost $\$ 4.663$ billion to capital flight between 1999 and 2001 (Punch, 2001:1-2).

On the domestic front a similar trend is real Mr. Vincent Azie Acting Auditor General reported that more than $\mathrm{N} 23$ billion was lost in 10 ministries in 2001 under the Obasanjo democracy (Newswatch, 2003:21-27). This figure represent financial frauds, embezzlements, payment for jobs not done, over invoicing, double debiting, payment without consent from approving authorities and other forms of governmentalities. Disturbed by this virus of governmentalities, Obasanjo noted "If we discount the funds from inflation, some of the states are receiving $500 \%$ more than the pre-1999 figures. Are we seeing this on the street and in the lives of the people" (Punch, 2005:8). While the gross National Income may have surged over time, neither the military nor civilian democrats have been able to create wealth, create jobs or bridge income gap. The emergence of the rogue aristocrats in government house (although largely under EFCC probe) points to a velocity of decay unknown under authoritarian developmentalism. However, the probe is part of the democratic infrastructure for installing the due process and 
accountability that can guarantee transition within transition.

\section{State and Society in a Neo-democracy}

The popular staple of contemporary development studies is that a basic condition of development is a reasonable level of state-society coherence and articulation; the general presumption in the blossoming literature being democracy is better suited to provide this environment. The dominant issues in the discourse on Nigerian state like elsewhere in Africa are manifold; the absence of relative autonomy of the state, the issue of state-society disjuncture and the repressive character of the post-colonial state constitute the central issues for intellectual contestation. The central concern of this paper in this section therefore, is to capture the character of the Nigerian state within the context of neodemocracy. Has state-society relations been leveraged by the events and political developments in Nigeria since 1999? In other words, has democracy changed the character of the Nigerian state for the better?

The notion of relative autonomy of the state so celebrated in classical western literature ${ }^{3}$ though contested with empirical evidence by Miliband (1973), has been equally controverted by a large body of empirical evidence (Ake, 1978, 1981; Alavi, 1979) from Africa and elsewhere in Asia, due to its incipient, inchoate and distorted character. The Nigerian state "... lacks legitimacy and consensus and has continually been run by cabals of civilian and military predators" (Akhaine, 2006) making for its susceptibility, vulnerability and abuse by the governing classes. Thus, the state degenerates into an instrument of the governing class as historical evidence since 1960 has revealed. The brazen corruption and use of state power for personal and class interest that overwhelmed the first republic 1960-66; its replication in military authoritarianism 1966-1979 and from 1983 to 1999 as well as in the democracies of 1979-1983 (Joseph, 1989), and 1999 to date are clear historical illustrations of class instrumentalism of state, regime credential not withstanding. The indigenisation decrees of 1972 and 1976 (Ebohon, 1985), the structural adjustment programmes and the consequent privatisation and commercialisation programmes of Babangiga, Abacha, Abubakar and Obasanjo regimes clearly demonstrated state partiality in resource distribution in favour of class interest. The loss of over $\$ 10$ billion tax payers money meant for repositioning NEPA to close allies of the Obasanjo family, the discounted sale of choice refineries and steel plants to Obasanjo's cronies; though now eventually reclaimed due to nation-wide criticism on his exit from office, are clear evidence of abuse of state power. In addition, discounted sales of a number of other choice industries by the Bureau for Public Enterprise to notable political office holders and their cronies in the name of Privatisation and Commercialisation confirm the Super-Story of a de-stated Societies or at best a veneer state under a democracy. The jumbo wage rise enjoyed by the army during military rule and Obasanjo compensation agenda for the political class, which was outside a national wages context lends more validity to class instrumentalism thesis. A second sphere of investigation examines the profile of state-society disjuncture in democratic regimes. In classical thinking and writing on the state in western societies, popular consensus is that the state was a derivative of the society. This view assumes state-society coherence. However, the vast literature on the state in post-colonial societies holds contrary view. The state is viewed as disconnected from society. More fundamentally, leaders of state in post-colonial formations would do any thing to undermine the society that is supposed to constitute the basis of state action. This is more so in authoritarian systems objectified by the political armies; where power is derived through the barrel of a gun. Adekanye (1995) made a case for the army as the objectification of state when he described the military rule as an occupation force with no strong civic attachment to society.

What has happened to state-society relations since 1999 in Nigeria? The hazy conclusion is that the personalist proclivities that undermined Nigerian praetorianism and institutional armies in the hands of the political armies was re-enacted under the Obasanjo praetorian democracy (Ebohon, 2008). It has been argued on the basis of empirical evidence that a brand of democracy carved around the personality of Obasanjo did not only undermine the institutions of state but further dwarfed the society in every sphere. The rigging of elections; through the manipulation of ballot boxes as well as the deployment of security apparati of state to cajole electoral fortunes in favour of preferred candidates clearly epitomised the growing irrelevance of the society in the national political process ${ }^{4}$. The onslaught by militants on the parents of successful politicians who migrated to the state realm and abandoned society is proof of growing statesociety disjuncture. This has become more 
rampant in the Niger Delta where hijacking and hostage taking has moved from foreign oil company workers to local elites who have links with members of the political class. Indeed, the disdainful use of state power for brazen corruption and self-enrichment like the military predators of the authoritarian junta, points to the political class as an alternative occupation force. The scope and the level of embezzlement and fraudulent diversion of public funds since 1999 express the growing moral disdain and increasing civic alienation of civil society from the state.

One distinct trait of the post-colonial and often times military authoritarian Nigerian state that has been isolated is its repressive character (Young, 1985, 1986). This character derives from the interest the state is inclined to serve. In general terms, the prime determinants of state behaviour has been summarised as: hegemony, security, autonomy, legitimisation and revenue (Ebohon and Emuedo, 2008). These objectives often drive the state in contradictory direction. However, contemporary post-colonial state draws its character from the logic of colonial rule in Nigeria (Young, 1986:26; Ekeh, 1976). Its basic character was repressive; lacking in accountability, the colonial state faced the challenge of establishing the authority and control needed for the optimisation of its primary objective in Nigeria; economic exploitation. Thus, the state became the ample arsenal for enacting arbitrary ordinances, which empowered the agencies of state to dominate and extract (Ebohon and Emuedo, 2008). On the collapse of civil democratic rule in January 1966, such colonial character typical of military authoritarianism became the logical replication of Nigerian state system. The pertinent question to ask is what impact has democracy made on the inherited repressive character of the Nigerian state since 1999.

The character of post-colonial repression has been very well demonstrated in handling of the Niger Delta crisis. Military repression was utilised to silence the agitation for ecosystem enhancement and the call for a review of the formula for sharing revenue. The murder of Ken Saro-Wiwa and other 8 Ogoni leaders following their demands for environment enhancement in 1995 marked the height of military repression and denial of human rights in the Niger Delta. It must be noted however, that similar state repression was unleashed against the Niger Delta people (parents and family members of Isaac Boro and his group were tortured to reveal their hideouts) during the first republic under Balewa. While subsequent military juntas after him may have ruled through the barrel of the gun, it is under the Obasanjo era that the most ruthless and repressive military actions were taken against the Niger Delta. The Odi massacre (The Guardian, Jan, 3 2004) (2483 killed: 1460 males and 1023 females) for which the Nigerian military offered apology and the killings of about 50 persons in Odioma community by a Joint Task Force of the Nigerian Army and Navy all in Bayelsa state, are classical examples of extreme state repression under democratic rule. It has been reported that management of the Niger Delta crisis under democracy since 2004 has claimed over 5000 lives. Meir estimates that violence in the Niger Delta, home to a majority of Nigerian oil reserves, kills about 1000 people a year on par with conflicts in Chechnya and Columbia (Ebohon and Emuedo, 2008). A number of convoluted military task forces such as "Operation Andoni", "Operation Hakuri", "Operation Flush", "Operation Restore Hope" were either created or inherited and strengthened under the new democracy to torture and persecute people in Bayelsa, Delta and River states.

Operation Hakuri was set up by Obasanjo few months after his inauguration in 1999 (The Guardian, Nov. 25, 1999) to protect oil wells, refineries and pipeline systems. In 2002, Operation Restore Hope was also set up to further strengthen the repressive machinery of state in the protection of the oil industry. This was due to the proliferation of militant youth groups and the up surge of vitriolic violent conflicts between these youth groups and the Nigerian security forces in the Niger Delta; aftermath of the Odi massacre.

\section{Conclusion: Beyond Democracy and Autocracy}

A popular staple of contemporary development analysts; democracy better propels development than autocracy is controverted by empirical evidence from the Nigerian experience. The pre-eminence of virus inter-facing across regime boundaries points to the roots of crisis reproduction and the failure of the Nigerian project since 1960. This has been illustrated in this paper by the persistence of endemic crisis and poverty of the Nigerian State and Nigerian politics in the context of alternative governments; military or democratic. It has been shown that the crisis of preceding regimes is often more than doubly replicated in the succeeding regimes; regime credentials notwithstanding.

Two fundamental explanations tend to suggests themselves for the nature of the contradictions at the base of popular western 
postulations on democracy and development. The first is that the over romanticised relationship between the two phenomena in popular liberal western scholarship lack empirical validity, scientific status and hence scientific utility. Secondly and closely linked to the foregoing, is the weakness of the science of social engineering in the liberal western tradition of scholarship engendered by the challenge of protecting capitalism and its political apparatus, democracy; against socialism and its political apparatus, authoritarianism. The conjectural effect of these postulations is the crystallisation of a convoluted mass of intellectual poverty that has been straight jacketing development analysts since bipolarism. Thus, bipolarism weakened and delayed the emergence of the science of social science and the utilitarian value of democracy and authoritarianism as social engineering projects.

Seeking refuge in developmental tempocentric proximity, a brief illustration of Asian experience will highlight the contradictions and character of intellectual poverty inherent in western discourse, to enable us articulate our conclusions. The contrasting development experiences of largely authoritarian East Asia and democratic South Asia - 1960s, 1970s and 1980s form our focus. It is common knowledge that over the three decades, average economic performance both in terms of per capita income and broader indicators like the human development index has been substantially better in the former region than in the latter (this is also the case in a bilateral comparison of the two largest countries in the world, one in the former region and one in the latter; China and India) (Bardhen, 2006:1-2).

The popular staple of new institutional economics and law is that a basic pre-condition of development is a minimum legal and contractual structure and a set of well defined property right; the general presumption in this literature is that democracy is better suited in providing this environment. This generalisation may be misleading, for instance, for more than three decades, the first Indonesian family or the KMT leadership in Taiwan provided a reasonably predictable and durable (even though corrupt) contractual environment for business to thrive, without the procedural formalities of a democracy. On the other hand, in a number of democratic regimes, in spite of the existence of an admirable legal contractual structure on paper, (the courts and the administrative arbitration machinery) are hopelessly clogged and under the circumstances, the businessman values his connection with the political class more than the legal niceties. (Bardhen, 2006:3)

Not all cases of public pressure that democracy may facilitate help development either; democracy may be particularly susceptive to populist pressure for immediate consumption, unproductive subsidies, autarchic trade policies and other particularistic demand that may harm long run investment and growth. Authoritarian rulers on the other hand, may have the capacity to resist such pressure based on commitment to development vision.

Historically, authoritarian regimes have come in different forms; some deriving their legitimacy from providing order and stability (like that of Franco in Spain, Rawlings in Ghana, Shore in Mananmer) some from rapid growth like (Park Chung Hee in South Korea). Indeed, Sah (1991) has powerfully argued that authoritarian regime exhibit a larger variance in economic performance than democracies.

The East Asia success story in development over the 60s, 70 s and 80 s owes much to some degree of insulation of the bureaucracy, in charge of formulating long-run development policies from the ravages of short-run pork barrel politics. The role-played by powerful semi-autonomous technocratic organisations like the economic planning bureau in South Korea and in the industrial development bureau in Taiwan clearly points in this direction. The popular claim is that authoritarianism made it less difficult for East Asia to sustain this insulation. However, it must be noted that post-war Japan successfully insulated parts of its bureaucracy without giving up on democracy.

In sustaining the insulation of bureaucracy In East Asia, emphasis was on the Weberian characteristics of the internal organisation of the state like highly selective meritocratic recruitment and long-term carrier reward for members of the bureaucracy. In this respect, such insulation covering the police, the army, the criminal justice system can as well drive development process under a democracy where the leaders can successfully sustain such insulation. However, this insulation can only be successfully implanted in a democratic context when and where political culture nurtured and groomed over a period of time constitutes the driving force of the political system. It would also depend on other variables like a reduction in income gap between the rich and the poor, the level of literacy, the durability, integrity and capacity of the institutions of the state, as well as people's belief in those institutions. 
Two conclusions can be drawn so far. The first is that neither of the Nigerian projects democracy or autocracy has fostered meaningful development since independence. If anything, the Nigerian experience has been a Super-Story of duplicitous as, replication of the symptoms and the crisis of underdevelopment from one regime to another. On the other hand, the Asian experience has proved that either of the two phenomena can propel development or under development depending on the nature of the intervening or suppressor variables in the national project. In this context, there is often a missing link in development discourse. The rise of Russia and China as Socialist regimes competing with France, Britain and the US, for super power pre-eminence question the scientific integrity of the ideological colourations of contemporary development analysis.

A new configuration that captures the state-democratic developmentalism and or stateautocratic developmentalism with the intervening or suppressor variables as mediators or mitigators of the development process offers alternative explanatory framework. The Nationalists developmentalism as intervening variable or personalist developmentalism as suppressor variables constitutes a potent analytic instruments. Nationalists developmentalism has been largely responsible for the success of authoritarian developmentalism in China, Russia, East Asia, while the same phenomenon promoted British, French, American, Japanese and other western successful democratic projects.

On the other hand, the crisis of statehood and state democratisation by the ruling postimperial elites could be largely responsible for the Nigerian projects like elsewhere in post-colonial states. Thus, state reinvention and the trajectory of national developmentalism to mediate the development of social forces in the state context has a vital role to play in the development project.

\section{Notes}

1. As used in this context, it has the intellectual ancestry in physical and biological systems, which seeks energic inputs within the systems to survive the treat of death. Social and political organisations similarly seek inputs from systems' environment even in revolutionary times to acquire ultimate equilibrium.
2. Such contending views are well discussed in Appadorai, A., pp. 19-37 and pp. 95- 110, cited in this work.

3. The blanket use of state apparati by the functionaries of state in Nigeria to advance the interest of the ruling and governing class in defiance of general societal interest does not only undermine the larger society from which the State is derived but equally points to its growing irrelevance, political decay and powerlessness.

\section{REFERENCES}

Adekanye, I.B., 2005. Military Occupation and Social Stratification. In Inaugural Lectures, 1, (1992 - 1997), (Ibadan: Ibadan University Press).

Ake, C., 1981. A Political Economy of Africa. (Nigeria: Longman).

Ake, C., 1978. Revolutionary Pressures in Africa. (London)

Alavi, H., 1979. The State in Post-Colonial Societies: Pakistan and Bangladesh in Goulborne, H. (ed.), Politics and the State in the Third World. London: Macmillan Press.

Apparodai, A., 2003. The Substance of Politics. (New Delhi: Oxford University Press.

Bardhen, P., 2006. Democracy and Development: A Complex Relationship (Mimio: University of California at Berkeley).

Campos, N., 1994. Why Does Democracy Foster Economic Development: An Assignment of Empirical Literature, (Mimio: UCLA).

Chizea, B. and lyare, T., 2006. Nigeria's Racing Ethnic Conflicts: The Role of Small Arms and Private Military Companies (PMCs) in The Constitution: A Journal of Constitutional Development. 6, (1):

Ebohon, S.I., 2008. "Post-Militarism: Provenance of Praetorian Democracy in Nigeria, 1999 - 2007". Seminar Paper Presented at the 
Benson Idahosa University, Benin City, Nigeria.

Ebohon, S.I., 1985. Nigerian Policy Towards Foreign Companies: A Study of Multinational Pharmaceutical Formulation Plants 1972 - 1983. (Umpublished P.hD Thesis University of Manchester).

Ebohon, S.I and Emuedo, C.O., 2008. State, Oilification and Combative Reactionism in the Niger Delta Region, Nigeria. Knowledge Review, 17, (1): December. pp 90-100.

Hughes, M. and Kroehler, C.J., et al 2002.Sociology: The Core $6^{\text {th }}$ ed, (New York: McGraw-Hill).

lyayi, F., 2006. "A Paper presented on background factors for Edos Future at Urokpota Hall, Benin City.

Joseph, R., 1986. Democracy and Prebend Politics in Nigeria: The Rise and Fall of the Second Republic. (Cambridge, England: Cambridge University Press).

Katz, D. and Kahn R., 1978. The Social Psychology of Organisations. 2n ed (John Wiley and Sons. Inc.).

Leys, C., 1096. "The Overdeveloped PostColonial State: A Re-examination" Review of African Political Economy, (5): (January - April).

Miliband, R., 1973. The State in Capitalist Society: The Analysis of the Western System of Power. (London: Quarlet Books).

Odion-Akhaine, S., 2006. Human Rights, Diplomacy and Democracy in Nigeria. In
The Constitution, A Journal of Constitutional Development. 6. (1):

Olatunji, D., 1995. "An Ideology for Decay". The Guardian, October 3.

Persson, T. and Tabellni, G., 2006. Democracy and Development: The Devil in the Details (Mimio Jan. 10.

Prezeworsky, A. and Limongi, 1993. "Political Regimes and Economic Growth". Journal of Political Perspectives, Summer.

Riker, H.W., 1965. Democracy in the United States, (London: Macmillan Press).

Ruechemeyer, D., 2001. On Democratic Equality (Stanford Conference Paper).

Sah, R.K, 1991. Fallibility in Human Organisations and Political System, Journal of Economic Perspectives. Spring.

Schmitter, P.C., 2003. The Quality of Democracy: The Ambiguous Virtues of Accountability. Mimio.

Swaison, J., 1977. The Rise of the National Bourgeoisie in Kenya. Review of African Political Economy, (8):.

Young, C. and Thomas, T., 1985. The Rise and Decline of the Zairian State. (Madison: University of Wisconsin Press).

Young, C., 1986. "Africa's Colonial Legacy". In Robert J., Berg and Jennifer Seymour Whitaker (eds.) Strategies of African Development (London, Berkeley, Los Angeles: University of California Press). 